\title{
The Economic Aspects of a Small Equine Boarding Operation in North Florida ${ }^{1}$
}

Julie Gatlin, Johann Krebs, P.J. van Blokland, and J.J. Haydu²

\section{Introduction}

Small property holders with lots of experience with horses might consider owning and managing a small equine boarding operation to supplement their income from permanent full-time jobs (Note: this type of operation will not sustain you by itself, nor is it recommended for someone unfamilar with caring for horses). This document outlines a typical 10-acre operation with pasture and stable for boarding 10 horses. It includes the costs and revenues of the boarding operation only, not the owner's residence and land beyond these 10 acres. Data refers to 2003 North Florida costs and prices.

\section{General Issues}

\section{Generalities}

Successfully marketing your equine boarding facility will maximize your revenue. Studies show that boarding facilities average an 80 percent occupancy rate, with clients changing facilities once a year.
Be familiar with the equine boarding market by identifying the demand for boarding horses, the number of prospective clients in the area, and the current supply of boarding stables nearby. Perform a SWOT (Strengths, Weaknesses, Opportunities, and Threats) analysis of competitors to help identify key areas such as their prices and services. Keys to a successful facility include location, safety, boarding barn aesthetics, and landscaping. Clients are interested in how well you maintain your facility.

Table 1 lists the recommended feed, worming, immunization, and farrier requirements that clients must follow so that horses being boarded stay healthy. Remember, one sick horse can jeopardize your business. To maximize horse health, have boarders sign an agreement that they will meet the guidelines for regular health maintenance of their horses. Insist on proof that a horse is negative Coggins and up-to-date on vaccinations and worming before it is allowed on the property. Keep a log on all horses to check off when horses are vaccinated, tested, wormed, and trimmed. Also, keep a monthly

1. This is EDIS document FE428, a publication of the Department of Food and Resource Economics, Florida Cooperative Extension Service, UF/IFAS, University of Florida, Gainesville, FL. Published February 2004. Please visit the EDIS website at http://edis.ifas.ufl.edu.

2. Julie Gatlin, former MAB graduate student, Department of Food and Resource Economics, University of Florida, Gainesville, FL; Johann Krebs, former MAB graduate student, Department of Food and Resource Economics, University of Florida, Gainesville, FL; P.J. van Blokland, Professor, Department of Food and Resource Economics, University of Florida, Gainesville, FL; and J.J. Haydu, Professor, Mid-Florida Research and Education Center, Apopka, FL; Florida Cooperative Extension Service, UF/IFAS, University of Florida, Gainesville, FL.

The use of trade names in this publication is solely for the purpose of providing specific information. UF/IFAS does not guarantee or warranty the products named, and references to them in this publication does not signify our approval to the exclusion of other products of suitable composition.

The Institute of Food and Agricultural Sciences (IFAS) is an Equal Employment Opportunity - Affirmative Action Employer authorized to provide research, educational information and other services only to individuals and institutions that function without regard to race, creed, color, religion, age, disability, sex, sexual orientation, marital status, national origin, political opinions or affiliations. For information on obtaining other extension publications, contact your county Cooperative Extension Service office. Florida Cooperative Extension Service / Institute of Food and Agricultural Sciences / University of Florida / Larry R. Arrington, Interim Dean 
record of all body-condition scores and a yearly record to check that their teeth are floated annually.

For owners to limit their liability, equine boarding operations should be set up as corporations so that only the operation's assets will be at risk (van Blokland, 2002). According to the Horse Industry Handbook (1993), you need to be honest with yourself and know your limitations.

\section{Zoning}

It is vital to know your county's restrictions, so check the local zoning requirements yourself. This information can be found by calling the county courthouse or looking up the county's website (look under Codes Enforcement-Zoning). Each county has its own way of identifying and naming zoned rural areas. Sometimes you can buy any type of zoned land and apply for a "justified" exemption for your boarding facility. Some counties have no areas zoned for boarding stables, but may allow you to petition for a special permit in addition to a development permit for commercial use.

Most counties have restrictions on the number of horses allowed per acre. Many restrict the number to 1 horse per acre, not including the residence area, for up to 10 acres (this restriction is generally dropped for areas larger than ten acres), or they allow horses but have specific community deed restrictions. For example, Marion County is "the horse capital of the world", so its restrictions favor horse operations. It allows up to 4 horses per acre for equine operations with less than 10 acres and lifts restrictions on larger operations.

\section{Agricultural Exemptions}

Obtaining an agricultural exemption for an equine business can be challenging because there are no set guidelines. Each county's property appraiser decides the restrictions to be imposed on county land. The property appraiser must identify your business as "good faith, commercial property use". Information on exemptions can be found by calling the county courthouse or looking up the county's website (look under Property Appraiser).
The property appraiser generally requires at least five acres, exclusive of any residence, for a property to qualify for a general agricultural exemption. Some counties will not allow an agricultural exemption for equine boarding or training facilities, but many will allow an exemption for broodmares (some boarding facilities add a small broodmare business to their operation). Generally, the rule is 3 broodmares (foaling annually) for every 15 acres, exclusive of the land used by the boarding facility.

\section{Investment Costs}

A wide range of costs exists for capital inputs (setting up the business), depending on many variables. The costs listed in Table 2 are typical for year 2003 in north Florida.

\section{Financing Costs}

Contact the agricultural loan departments of banks for financing information. When making the application, it is helpful and informative to bring along an estimate of the capital required and a forecast of annual revenues and expenses. Farm loans for pastureland with a residence, or barn and pasture with a residence, are usually only available for 15 or 20 years (Farm Credit of North Florida, 2002). For our model, we estimated financing at 7.5 percent for 15 years, with a 20 percent down payment.

\section{Land Acquisition Costs}

Land prices vary according to location. Land closest to metro areas costs more than rural land. In North Florida, the typical price of land for an equine facility is $\$ 5,000$ per acre (based on real estate quotes in 2003). Most horse owners looking at boarding their horses do not want to drive more than 15 miles, and they want suitable riding places nearby. If your operation does not have its own riding facilities, you may want to consider buying near a state park that allows horseback riding or near a horse show/park facility.

When buying land, select land that is high, rolling, and well-drained. Choose land that has sandy loam soil over a limestone base for water-holding capacity. This will minimize fertilizer loss, while keeping pastures green, and will allow proper 
drainage away from the barn. Avoid purchasing land with light sugar sand soil, which is not conducive for pasture growth.

Also, purchase land that includes an established Bahiagrass pasture and a pond; otherwise, a pasture will have to be planted and a pond installed. Horses may not be placed on pasture for three months after seeding (assuming adequate rainfall) to ensure growth, and it usually takes two growing seasons for pasture to become established (Chambliss, 2002). Another thing you should consider are trees for shade, but be sure to place fencing around the trees, as the horses will eat and kill any trees within reach.

\section{Capital Input Costs}

These are the costs incurred for setting up a home-based business.

\section{Fencing and Gating}

Complete peripheral, four-board fencing is recommended for maximum safety; some equine insurance companies require it (based on 2003 prices, four-board fencing costs approximately $\$ 4.50$ per foot). Avoid barbwire because it causes serious injury to horses (e.g., cut tendons and stomachs). The pasture should be divided into two or more paddocks with at least a 12-foot lane between them for safety (some horses do not get along, and this will prevent them from hurting each other). You may also want to separate geldings and mares in different pastures. Angling fencing corners is recommended to prevent dominant horses from trapping the other horses into corners. (Safety Note: many injuries happen 30 minutes before feeding time).

The type of gating you use is important. Tubular steel gates are recommended because they minimize risk for the horses. (Based on 2003 prices, a 12-foot tubular steel gate costs approximately \$55). Do not use aluminum gates, which are dangerous to horses because the cross braces in these gates have eight places for a horse to trap one of its feet and aluminum is easily broken.

\section{Watering System}

Water is an important nutrient for a horse, with the average horse consuming about 12 gallons per day. Make sure there is plenty of clean, fresh water available at all times. Test the water occasionally to verify that it is the proper quality for horses.

- Ponds: A pond is needed not only for drinking, but also for emergencies, such as fire or power outages, when well pumps do not work. (Based on 2003 prices, a quarter-acre pond costs approximately $\$ 4,000$.)

- Wells: Place wells on high ground and locate them near roads for easy servicing. Do not run any water lines under buildings. Install cut-off valves at strategic locations to facilitate service. (Based on 2003 prices, one well and pump costs approximately $\$ 2,500)$.

\section{- Automatic Watering Systems: Automatic} waterers are time-saving devices, which should be connected to wells with PVC pipes. (Based on 2003 prices, a large trough costs $\$ 60$, and a float to regulate water level costs $\$ 15$, so the total cost of an automatic waterer is $\$ 75$.)

- Septic System: A septic system is recommended for stables/barns. (Based on 2003 prices, a septic system costs about $\$ 5,000$ to install.)

\section{Barns and Facilities}

A shedrow barn is the best style of barn for Florida because it provides good ventilation. It should have $12 \times 12$-foot horse stalls with sliding doors for safety. Do not skimp on the hardware here-you want these doors to roll easily and to be durable. The barn should also include a feed room, tack room, and bathroom, all with cement floors. The building plan should include easy access from all stalls to the feed room. (Based on 2003 prices, the average cost for building a shedrow barn is $\$ 13$ per square foot, so a 10 -stall barn with these features would average 4,800 square feet and cost about $\$ 63,000$.)

The barn should have a place for nearby convenient parking, with room for a trailer turn-around. Most county zonings usually require buildings to be a certain distance from property 
boundary lines (100 to 300 feet). It is recommended that barns (and pastures) be located in an area behind the owner's residence for better security.

Miscellaneous barn expenses include electrical hookups (approximately $\$ 300$ for small barns and $\$ 600$ for large barns); barn fans (approximately \$250); and work equipment such as shovels, rakes, buckets, fire extinguishers, etc. (approximately $\$ 200$ for 5-horse barns and $\$ 400$ for 10-horse barns).

The barn should have a fire safety system that includes a ceiling sprinkler system; easily accessible, working fire extinguishers placed every 30 feet inside the barn; smoke and fire alarms; and a monitoring system that will sound the alarm if no one is at the barn. Check all fire safety equipment at least twice a year to make sure it works properly. Also, install a grounded lightning-rod system to protect the barn during electrical storms.

Other barn-related facilities you will need are as follows:

- Roads: A paved road may not be necessary. Limerock road prices vary according to length and what type of ground is already there. (Based on 2003 prices, the typical price for 200 feet of a 10-foot wide road built on a 6-inch limerock base would cost $\$ 1,500$.)

-Vehicles: Owners can use their personal trucks for an equine business (estimated 50 percent business use). For example, the capital expenditure for a $\$ 40,000$ truck would be $\$ 20,000$. The operation may also want to have horse trailers for transporting horses.

- Feed Storage Sheds: These sheds should have a roof and a cement floor with a ventiliation system to keep the feed dry. (Based on 2003 prices, at $\$ 5.00$ per square foot, a 200 square foot feed shed would cost $\$ 1,000$.)

- Compost Bins: These are recommended for recycling horse manure. A compost bin can be built with cinder blocks and cement for approximately $\$ 100$. See Composting Horse Manure for more information (Ott, Johnson, and Nordstedt, 2000).
- Warm-Up/Training Pens: These pens should measure at least 60 feet in diameter and can be constructed for about $\$ 1,000$.

- Jumps: Jumps can range in price from $\$ 50$ to $\$ 500$ each. Some boarders may want to provide their own special jumps, so storage space must be provided for them.

- Wash Racks: These should be provided to the boarders. A wash rack is a concrete slab (10x12 feet), with railing around three sides. (Based on 2003 prices, a wash rack would cost about \$400.)

\section{Miscellaneous}

- Office: You can claim furniture, equipment, and supplies, and perhaps a portion of your home for income tax deductions. For our model, we estimate a $\$ 2,500$ initial investment $\$ 400$ for a desk; $\$ 2,000$ for a computer; $\$ 50$ for a phone; and $\$ 50$ for office supplies).

- Advertising: This includes advertisements in local newspapers and horse journals, and fliers at local feed stores and horse clubs (estimated cost is $\$ 150$ ).

- Lawyers and Legal Fees: You will need to hire a lawyer to create a corporation for your business and to advise you (estimated cost is $\$ 3,000$ ).

\section{Annual Budgets}

In addition to capital input (set-up) costs, it is also necessary to produce annual budgets, starting with total operating costs of the project. These costs are cash costs, overhead costs, and depreciation costs. Table 3 illustrates a budget cost analysis.

\section{Cash Costs}

\section{Business Operating Outlays}

- Mortgage Interest: This will vary. As an example, we will estimate the mortgage at $7.5 \%$.

- Property Taxes: Millage rates vary per area from 16 to 25 (typical North Florida farm millage rate is 20). This rate is used to estimate yearly real estate taxes for each option model. 
- Equine and Property Insurance: Commercial equine establishments require specific coverage. A $\$ 1$ million general liability insurance policy for an equine operation typically costs $\$ 600$ per year. Property insurance for a barn typically costs $\$ 1$ for every $\$ 100$ of coverage (a $\$ 63,000$ barn would cost $\$ 630$ per year).

- Farm Operating Utilities: Electricity only.

\section{Maintenance}

- Barns: Maintenance is estimated at $\$ 400$ per year for a 5-horse barn and $\$ 900$ per year for a 10-horse barn.

- Fences: Maintenance is estimated at $\$ 300$ per year.

- Farm Supplies: These are estimated at $\$ 180$ per year for a 5-horse barn and $\$ 360$ per year for a 10-horse barn.

- Stall Bedding: Each stall needs 50 pounds of straw for bedding. Cleaning stalls daily will use approximately 150 pounds of straw per week, per horse, or 7,800 pounds of straw per year (150 pounds $x 52$ weeks). If straw costs $\$ 100$ per ton, total straw cost would be $\$ 390$ per year, per horse (3.9 tons x $\$ 100$ per ton). Shavings is an alternative type of bedding. It is more expensive, but less labor intensive, and produces lower waste volume than straw.

\section{Forage Management Program}

Fertilizer: First, have the soil tested to determine if the correct nutrients and $\mathrm{pH}$ are present. Some fertilizer suppliers and feed stores do this for free. For Bahiagrass, apply fertilizer in late January, February, or early March. You can contract a fertilizer or feed company to do this for an average price of $\$ 42.00$ per acre (fertilizer and application), or do it yourself with a 15-5-10 or 20-5-10 complete fertilizer at 400 pounds per acre. In addition, Bahiagrass needs a soil $\mathrm{pH}$ of 5.5. If the $\mathrm{pH}$ is less than 5.5, apply lime in the fall (one ton per acre will raise soil one $\mathrm{pH}$ at $\$ 25$ per ton). It usually takes 6 to 12 months after liming to reach the target $\mathrm{pH}$. Lime applications should be repeated every 3 to 5 years. Micronutrients also need to be applied every 3 to 5 years ( 25 pound per acre).
If Calcium equals less than 600 pounds per acre, apply limestone at 1 ton per acre, and if Magnesium equals less than 100 pounds per acre, apply dolomite at 1 ton per acre.

Weed Control: A product named Ally is recommended for weed control, applied at 0.3 ounces per acre in late May to August. Make sure your farm is free of plants that may harm horses. For detailed information about Bahiagrass pasture management, see UF/IFAS publications "Plants that poison farm animals" (West and Emmel, 1997), "Fertilization of established Bahiagrass pasture in Florida" (Sumner, 2000), "Bahiagrass" (Chambliss, 2002), and "Weeds in the sunshine: Weed management in pastures and rangeland" (Tredaway et al., 2003).

Winter Ryegrass: This grass will boost your pasture's protein level in the winter months. Plant the grass seeds in October, November, or December using 25 pounds per acre, along with a 10-5-10 fertilizer at 400 pounds per acre. (Based on 2003 prices, a 50-pound bag of seed costs about \$19). In addition, occasionally drag the pastures to spread manure, especially when it is hot and dry. This kills parasite eggs, spreads nutrients, and keeps grazing more uniform.

\section{Overhead Costs}

- Office Supplies: Estimate $\$ 60$ per year.

- Business Office Utilities: Electricity only.

- Accountant: Estimate $\$ 300$ per year.

- Lawyer: Estimate \$1,000 per year.

\section{Depreciation Costs}

- Barn Depreciation: Allow 15 years, using the straight-line method.

- Fencing Depreciation: Allow 7 years for fence depreciation.

- Vehicle Depreciation: Allow 7 years, based on the straight-line method-in this case, $\$ 2,857$ per year $(\$ 20,000 \div 7$ years $)$. 


\section{Annual Gross Income}

The estimated annual gross income for a 10-horse operation is $\$ 39,000$ ( $\$ 325$ per month, per horse).

\section{Net Farm Income and TIPS}

After the Operating Costs (cash costs, overhead costs, and depreciation costs) have been determined, they are subtracted from the Annual Gross Income, giving the Net Farm Income (NFI) for each model. This is the amount from which (T)axes, $\operatorname{Re}(\mathrm{I})$ nvestment, (P)rincipal payments, and the owner's (S)alary are paid (acronym: TIPS). This is where the business manager has to make decisions. How much NFI should be allocated to each category of TIPS? Good, average, and indifferent managers can be identified largely by how they allocate TIPS.

Taxes are pretty fixed for a known taxable income. However, if NFI shows that there is a sizable tax bill due AND the project needs expansion, the manager should look for opportunities in depreciable assets to reduce the tax bill. After this decision is made, subtract taxes from the NFI to give Net Income (NI), which is identical to earnings or profit. There are, of course, only 3 items left to allocate-Salary, Reinvestment, and Principal (acronym: SIP). The order here is crucial. Pay yourself first (the family will thank you for this). Then decide how much you need to re-invest. Realize that depositing cash in the bank from the NI or NFI is considered a reinvestment under GAAP (generally accepted accounting principles). The remainder goes to pay the principal.

These numbers must all be included in the budget (the budget shows what you think you will pay and what you think you will bring into the business). The difference is NFI, and after taxes, NI. Consequently the real decision-making starts with NFI and NI allocations. These numbers must then be sold to the equity suppliers (family) and debt suppliers (lenders) of the project. Only when all are as satisfied as possible, can the budget be started. The above numbers show that NFI is around $\$ 12,840$. Having committed to borrow over $\$ 140,000$ at 7.5 percent for 15 years, there is no money available for salary (Table 4). Make sure that you know this before you invest in this lifestyle. Reducing debt by providing more up-front equity obviously will change things, but it is unlikely that any salary from an operation of this size will be significant.

\section{References}

Chambliss, C.G. 2002. Bahiagrass. Electronic Data Information Source (EDIS) AA184. Department of Agronomy, University of Florida, Gainesville, FL. http://edis.ifas.ufl.edu/AA184.

Farm Credit of North Florida. 2002. Personal communication.

Gatlin, Julie, P.J. van Blokland, Johann Krebs, and J.J. Haydu. 2003. A comparison of economic feasibility of three small equine boarding operations in North Florida. Teaching and Learning Paper TLP-03-06, Department of Food and Resource Economics, University of Florida, Gainesville, FL.

Horse Industry Handbook. 1993. The business of horsemen: Keys to success. Lexington, KY: American Youth Horse Council.

Ott, E.A., E.L. Johnson, and R.A. Nordstedt. 2000. Composting horse manure. Electronic Data Information Source (EDIS) AN040. Department of Animal Science, University of Florida, Gainesville, FL. http://eids.ifas.ufl.edu/AN040.

Sumner, Sid. 2000. Fertilization of established bahiagrass pasture in Florida. UF/IFAS Circular 916. University of Florida, Gainesville, FL. http://rcrec-ona.ifas.ufl.edu/cir916.html

Tredaway Ducar, J.A., G.E. MacDonald, B.J. Brecke, and J.J. Mullahey. 2003. Weeds in the sunshine: Weed management in pastures and rangeland. Electronic Data Information Source (EDIS) WG006, Department of Agronomy, University of Florida, Gainesville, FL. http://edis.ifas.ufl.edu/WG006.

van Blokland, P.J. 2002. Personal communication (August).

West, Erdman, M.W. Emmel, and K.D. Perkins. 1997 Plants that poison farm animals. UF/IFAS Bulletin 510A, University of Florida, Gainesville, FL. 
Table 1. Recommended Horse Health Plan Requirements.

\begin{tabular}{|c|c|}
\hline Items & Recommended Requirements \\
\hline \multicolumn{2}{|l|}{ Feed } \\
\hline Concentrates & $\begin{array}{l}\text { Feed should be limited to } 0.05 \text { to } 0.10 \text { percent body weight, depending on the } \\
\text { activity of the horse. Feed at regular times twice daily. }\end{array}$ \\
\hline Roughage & $\begin{array}{l}\text { Roughage should be limited to } 1 \text { to } 2 \text { percent body weight, depending on the } \\
\text { availability of pasture and the activity of the horse. Horses also need hay if they are } \\
\text { stalled for periods of over } 3 \text { hours per day. }\end{array}$ \\
\hline Energy Supplements & $\begin{array}{l}\text { Provide protein, minerals, and vitamin supplements equal to } 1 \text { percent body weight } \\
\text { daily in concentrated form or feed. Note: a mineral block should be provided in all } \\
\text { pastures. }\end{array}$ \\
\hline \multicolumn{2}{|l|}{ Immunizations } \\
\hline Once a Year & $\begin{array}{l}\text { - Combination Encephalitis and Tetanus } \\
\text { - Rabies }\end{array}$ \\
\hline Twice a Year & $\begin{array}{l}\text { - Encephalitis } \\
\text { - West Nile Virus }\end{array}$ \\
\hline Outbreaks & $\begin{array}{l}\text { - Flu } \\
\text { - Strangles } \\
\cdot \text { PHF }\end{array}$ \\
\hline Tests & A Coggins Test should be performed at least once yearly. \\
\hline Wormings & $\begin{array}{l}\text { - Horses must be wormed every } 3 \text { months, preferably with Ivermectin } \\
\text { - Strongid should be used for at least } 1 \text { of the wormings }\end{array}$ \\
\hline Farrier Expenses & $\begin{array}{l}\text { - A horse's hooves should be trimmed every } 8 \text { weeks if not shod } \\
\text { - A horse's hooves should be trimmed every } 6 \text { weeks if shod }\end{array}$ \\
\hline
\end{tabular}


Table 2. Capital Investment Cost Analysis.

\begin{tabular}{|c|c|}
\hline Capital Investment & 10 Acres / 10 Horses \\
\hline Land/acre with pasture ( $\$ 5,000$ per acre) & $\$ 50,000$ \\
\hline Fencing (4-board at $\$ 4.50$ per square foot, installed) & $\$ 18,000$ \\
\hline Tubular Steel Gates (12-feet at $\$ 55$ each x 4) & $\$ 220$ \\
\hline \multicolumn{2}{|l|}{ Water } \\
\hline Pond (digging cost per $1 / 4$ acre) & $\$ 4,000$ \\
\hline Well \& Pump & $\$ 2,500$ \\
\hline Automatic Waterer ( $\$ 75$ each $\times 2$ ) & $\$ 150$ \\
\hline Septic System & $\$ 5,000$ \\
\hline Shedrow Barn ( $\$ 13$ per square foot) & $\$ 63,000$ \\
\hline Electric Hookup & $\$ 600$ \\
\hline Feed Room (200 square feet at $\$ 5$ per square foot) & $\$ 600$ \\
\hline Truck (half the cost of $\$ 40,000$ ) & $\$ 20,000$ \\
\hline Limerock Road (200 feet $\times 10$ feet $\times 6$ inches) & $\$ 1,500$ \\
\hline 60-foot Round Pen & $\$ 1,000$ \\
\hline 120-foot Riding Arena & $\$ 2,000$ \\
\hline Jumps & $\$ 300$ \\
\hline Wash Racks ( $\$ 400$ each x 2) & $\$ 800$ \\
\hline Compost Bin & $\$ 100$ \\
\hline \multicolumn{2}{|l|}{ Farm Supplies } \\
\hline Barn Fan & $\$ 250$ \\
\hline Shovels, Rakes, Buckets, etc. & $\$ 400$ \\
\hline Office Supplies (computer, phone, furniture, etc.) & $\$ 2,500$ \\
\hline Lawyer & $\$ 1,000$ \\
\hline Legal Fees (Creating a corporation) & $\$ 2,000$ \\
\hline TOTALS & $\$ 175,920$ \\
\hline 20 Percent Down & $\$ 35,064$ \\
\hline Loan Amount & $\$ 140,256$ \\
\hline Monthly Principal and Interest (15-Year Term) & $\$ 1,300.19$ \\
\hline
\end{tabular}

Table 3. Annual Budget Cost Analysis.

\begin{tabular}{|lc|}
\hline \hline $\begin{array}{l}\text { Annual Equine Boarding Budget } \\
\text { (based on 15-year term mortgage) }\end{array}$ & $\mathbf{1 0}$ Acres / 10 Horses \\
\hline $\begin{array}{l}\text { Annual Gross Income } \\
\text { Annual Costs }\end{array} \quad$ 15 Years (Land \& Barn) \\
Cash Costs & \\
$\quad$ Interest on Loan (Yearly Average) & \\
Land Taxes (Average Millage: 20) & $\$ 6,252$ \\
Utilities (Farm Only) & $\$ 1,000$ \\
Fertilizer & $\$ 360$ \\
Winter Rye (Seeds \& Plants) & $\$ 420$ \\
Stall Bedding & $\$ 100$ \\
Barn \& Fence Maintenance & $\$ 3,900$ \\
Farm Supplies & $\$ 1,200$ \\
\hline \hline
\end{tabular}


Table 3. Annual Budget Cost Analysis.

\begin{tabular}{|c|c|c|}
\hline $\begin{array}{l}\text { Annual Equine Boarding Budget } \\
\text { (based on 15-year term mortgage) }\end{array}$ & 10 Acres / 10 Horses & \\
\hline & 15 Years (Land \& Barn) & \\
\hline Advertising & $\$ 150$ & \\
\hline Insurance (Equine and Property Liability) & $\$ 1,230$ & \\
\hline Annual Total Cash Costs & & $\$ 14,972$ \\
\hline \multicolumn{3}{|l|}{ Overhead Costs } \\
\hline Office Supplies & $\$ 60$ & \\
\hline Lawyer & $\$ 1,000$ & \\
\hline Accountant & $\$ 300$ & \\
\hline Utilities (Office Only) & $\$ 200$ & \\
\hline Annual Total Overhead Costs & & $\$ 1,560$ \\
\hline \multicolumn{3}{|l|}{ Depreciation Costs } \\
\hline Barn Depreciation (15 Years) & $\$ 4,200$ & \\
\hline Fencing Depreciation (7 Years) & $\$ 2,571$ & \\
\hline Truck Depreciation (7 Years) & $\$ 2,857$ & \\
\hline Annual Total Depreciation Costs & & $\$ 9,628$ \\
\hline Total Annual Costs & & $\$ 26,160$ \\
\hline Annual Net Farm Income (NFI) & & $\$ 12,840$ \\
\hline Original Investment & $\$ 175,320$ & \\
\hline Annual ROI (NFI/Original Investment) & $7.32 \%$ & \\
\hline \multicolumn{3}{|l|}{ TIPS (Paid from NFI } \\
\hline (T) Annual Taxes (Income and FICA) & $\$ 1,284$ & \\
\hline (I) Annual Re-Investment & $\$ 2,206$ & \\
\hline (P) Annual Principal Payments on Loan & $\$ 9,350$ & \\
\hline (S) Annual Salary & & \\
\hline Total TIPS (Must $=$ NFI) & $\$ 12,840$ & \\
\hline Total NFI & & $\$ 12,840$ \\
\hline
\end{tabular}

Table 4. Financial Summary.

\begin{tabular}{|lc|}
\hline \hline Items & Cost \\
\hline Interest Rate & $7.5 \%$ \\
Down Payment & $20 \%$ \\
Length of Mortgage (Years) & 15 Years \\
Pasture \& Stall Boarding Per Horse, Per Month & $\$ 325$ \\
$(10$ acres / 10 horses) & \\
Original Investment-Capital Expenditures & $\$ 175,320$ \\
Net Farm Income Total & $\$ 12,840$ \\
{$[$ Annual Gross Income minus Total Annual Costs $(\$ 39,000-\$ 26,160)]$} & \\
Salary After Expenses & $\$ 0$ \\
Debt Repayment Annually & $\$ 15,600$ \\
\hline \hline
\end{tabular}

